\title{
Analysis of Interior Design of Restaurants with Reference to Ambience and Customer Gratification
}

\author{
Sadia Farooq ${ }^{1}$, Faiza Zubair ${ }^{2}$, Mohammad Arif Kamal, \\ ${ }^{1}$ Department of Science, University of Home Economics, Pakistan \\ ${ }^{2}$ Department of Family and Consumer Sciences, University of Home Economics, Pakistan \\ ${ }^{3}$ Architecture Section, Aligarh Muslim University, India
}

Received July 30, 2020; Revised August 31, 2020; Accepted September 29, 2020

\section{Cite This Paper in the following Citation Styles}

(a): [1] Sadia Farooq, Faiza Zubair, Mohammad Arif Kamal , "Analysis of Interior Design of Restaurants with Reference to Ambience and Customer Gratification," Civil Engineering and Architecture, Vol. 8, No. 5, pp. 1019 - 1027, 2020. DOI: 10.13189/cea.2020.080528.

(b): Sadia Farooq, Faiza Zubair, Mohammad Arif Kamal (2020). Analysis of Interior Design of Restaurants with Reference to Ambience and Customer Gratification. Civil Engineering and Architecture, 8(5), 1019 - 1027. DOI: 10.13189/cea.2020.080528.

Copyright $@ 2020$ by authors, all rights reserved. Authors agree that this article remains permanently open access under the terms of the Creative Commons Attribution License 4.0 International License

\begin{abstract}
This study introduces an investigation into the effect of ambience on customer's gratification at the restaurants where numerous regular alterations in color, layout, light, aroma, cooling temperature, décor etc. are being done. Restaurateurs' goal is always to generate income for which they do alterations in their buildings' interiors. Relationship between customer gratification and three ambiences' features color, light and cooling is observed in two restaurants, named, Lahore View and Jasmine restaurants situated in Shalimar Tower Hotel, Lahore. A sample of 354 customers from these two restaurants was taken. The correlation coefficient between the income and dine in frequency was found to be highly significant leading to the conclusion that as income increases the dining frequency also increased. Associations between customer's satisfaction and demographic feature like income and gender were also studied, which were found statistically insignificant. To analyze the impact of ambient color, light and cooling on customer's gratification, a binary logistic regression model is applied with color, light and cooling factors as predictors. The regression was found to be highly significant with significant model parameters leading to the conclusion that color, cooling and lightning improvements can help in increasing customer's satisfaction which will eventually lead to the increase revenue generation.
\end{abstract}

Keywords Interior Design, Restaurants, Ambience, Customer Gratification

\section{Introduction}

The Customer gratification is for the most part associated with service feature in the eatery business [1] instead of worrying on ambience of the spot. The restaurateurs have a demand to clarify this gap in researches, to analyze the impact of ambience on customers' gratification because most of the people do not consider ambience a factor to increase revenue even it is. The studies in relation to customer gratification, ambience and revenue are limited [2]. Ambience can include a wide range of features such as exterior and interior layout, color, light, temperature, music, odor [3][4][5][6][7][8]. Most of researchers like Oliver, Kivela, Jordaan, Prinsloo, Choi, Chu and Park agreed that customer gratification is important to restaurateurs because patron return depends on it, repetition in discussions, recommendations and revenue generation. The dimensions of ambient features, color, light, and cooling were researched and discussed, separately [9][10][11][12][13].

The Restaurateurs may stress on continually changing the design of the restaurants including colors, light, cooling, and employee's style but the impact of the alterations on ultimate users is also not extensively or entirely documented [14]. There were a number of restaurants in Lahore which are struggling to compete in the market, they 
not only stress on the quality of food but also prefer the ambience to attract customers. The two restaurants present in Shalimar Tower hotel, were selected, named, Jasmine restaurant and Lahore View restaurant. The reason to select the restaurants was the alterations were regularly being made in the interiors of the restaurants but not being analyzed. The objectives were set to find out the connection between customer gratification and ambient factors such as color, light and cooling, given below:

- To analyze the impact of demographic characteristics on customer's satisfaction.

- $\quad$ To find out the relationship between color, cooling and lights in the restaurants on customers' gratification.

\section{Literature Review}

The literature is all about the ambient features and their linkage to the customer gratification.

\subsection{Customer Gratification and Ambient Conditions}

The customer gratification is a relationship between professional benefits and administrative strategies to fulfil customer demands. Increasing significant level of client satisfaction is critical to organizations in light of the fact that fulfilled clients and to utilize a wide scope of administration [15][16][17][18]. Customers are the sole explanation behind the presence of business foundations [19]. Lim suggests that, clients' final gratification can have critical impact associated with ambient conditions inside the eating place [20]. Researchers have distinguished ambient settings as a condition that influence impression of human reactions related to surroundings [21][22]. Surrounding conditions envelop a variety of foundation qualities of the earth, for example, design, temperature, color, light, commotion, music, and aroma [3][4][5].

\subsection{Customer Gratification and Ambient Color}

The utilization of appropriate colors in interiors of a restaurant can make the place practically feasible and acceptable to the customer and can impact of restaurant incomings [23]. Bright colors, in general impress and arouse emotions while deep warm and casual light shades appear to advance leisure and repose [24]. The hues are differentiated into hot and light colors like red, orange and yellow are considered to be hot while cool colors are green, blue and violet. Hot colors show people, the imprint of hot agreeable conditions [11]. The cool colors also, make comfortable places which contribute in customer appreciation [23].

\subsection{Customer Gratification and Ambient Light}

A restaurant, appropriate light is required to look at the food at its best by the customer. The conclusion is that all efforts are for the customer to be satisfied [25][26]. Therefore, the restaurant required to light each table individually, to create its own ambience [27]. Light can make the place cool and calm for the enjoyment of the services and experience. Customers speak more politely and delicately when lights are dim [28]. Light can be one of the most dominant physical features which influence the most in the restaurants [29]. Light is also the impression which a restaurateur wants to create [27]. The light can distinguish the place to have a unique experience than in any other place. The pioneer of the light research, Flynn, Hendrick, Spencer, Martyniuk, investigated the impact of light on customer feelings and attitude so that light will play a role as an ambient attribute [30][31][32].

\subsection{Customer Gratification and Ambient Cooling}

The challenge of maintaining a business includes diverse temperature and individuals' varying desires which must be understood and accomplished [26]. There are a lot of requirement in a restaurant such as proper ventilation, water purification, appropriate temperature etc. but the result must be in form of satisfied diners with appropriate ambience. The constant temperature can provide a consistent patron behavior [26]. Restaurateurs use air conditioning method to maintain the temperature of restaurant. The temperature imbalance can damage the overall impact of a restaurant because the customers would not like too hot or cold according to climate outside and can eventually damage the restaurant image. These outcomes in lost revenue, in this manner, the parity must be accomplished through cooling. Huang et al explored on the impacts of surrounding cooling on item inclinations and budgetary basic leadership. Results featured that agreeable encompassing cooling impact shopper inclination for similarity. Clients have no indistinguishable physical and enthusiastic marks, in this way, restaurateurs should locate a shared belief where the larger number is content. This can result in the loss of revenue or profit. The uniformity is required through constant temperature studied the effects of ambient low or required temperature to be preferred on items' likeness and money decisions. The results highlighted that the constant temperature provides comfort to the customers and impact on their preferences. Customers are always not satisfied on one choice which seems difficult to achieve but restaurateurs must stress on the preferences of majority of the people [33].

\section{Research Methodology}

The causal research design was studied to find out the cause and effect relationship of customer gratification and ambience [34]. The population was the customers of all the restaurants who offer regular alterations in their interior 
design along with food quality or service, to welcome and increase their customers and ultimately to increase revenue. Two restaurants, named, restaurant 1, Lahore View (Fig 1) and restaurant 2, Jasmine (Fig 2) situated in Shalimar Tower Hotel, Lahore were selected. The ambience which is showing interior elements, furniture, color scheme, lighting (Fig. 3,4,5,6) and even air conditioning unit is visible (Fig 2,6) in below given pictures. The technique used for the study was Simple Random Sampling Technique. The sample size was 354 .

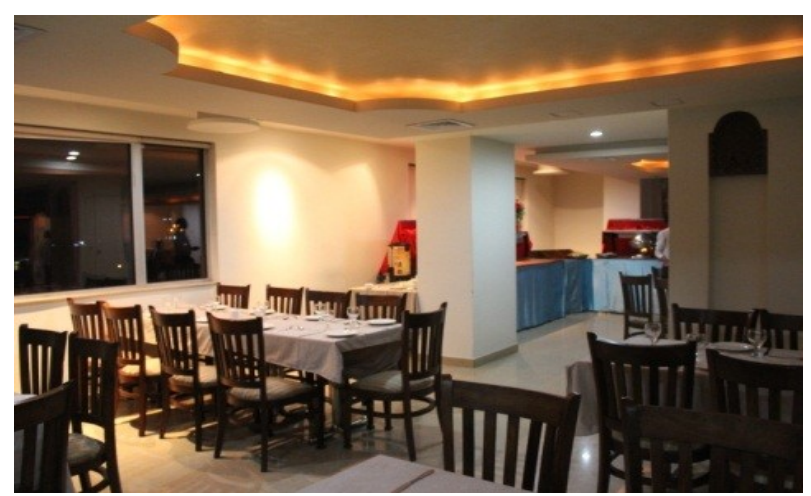

Figure 1. Restaurant 1 Furniture and Ambience

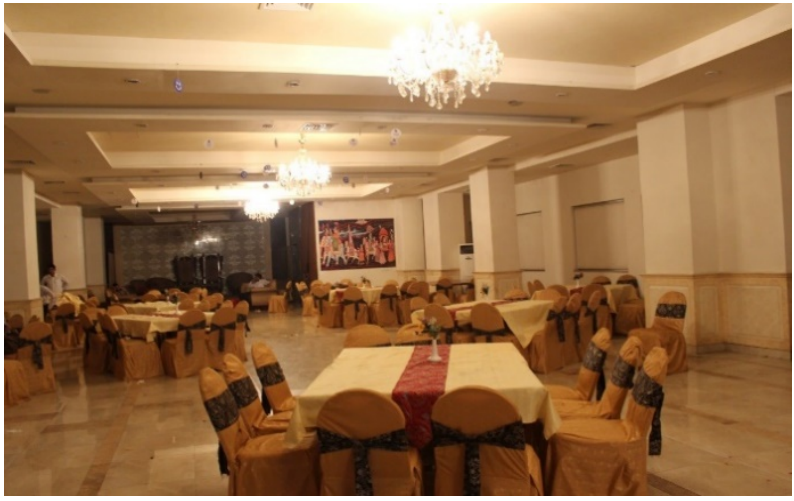

Figure 2. Restaurant 2 Furniture and Ambience

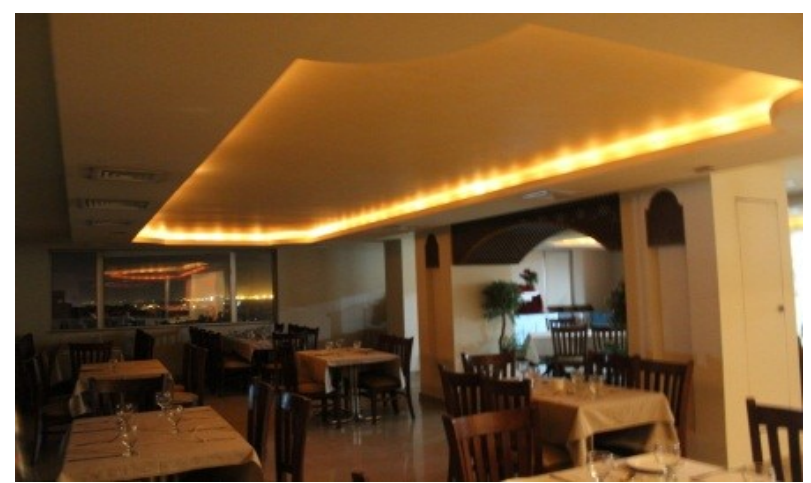

Figure 3. Restaurant 1 with Rope Lighting

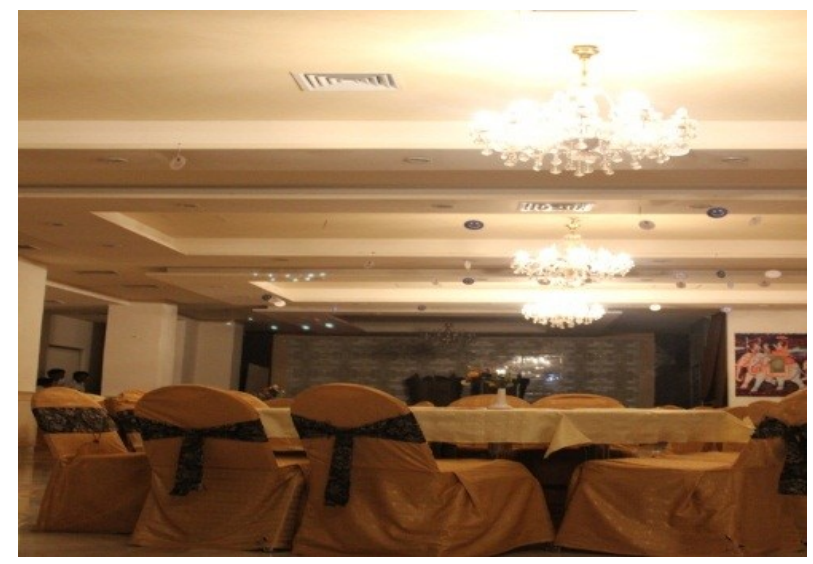

Figure 4. Restaurant 2 with Chandeliers

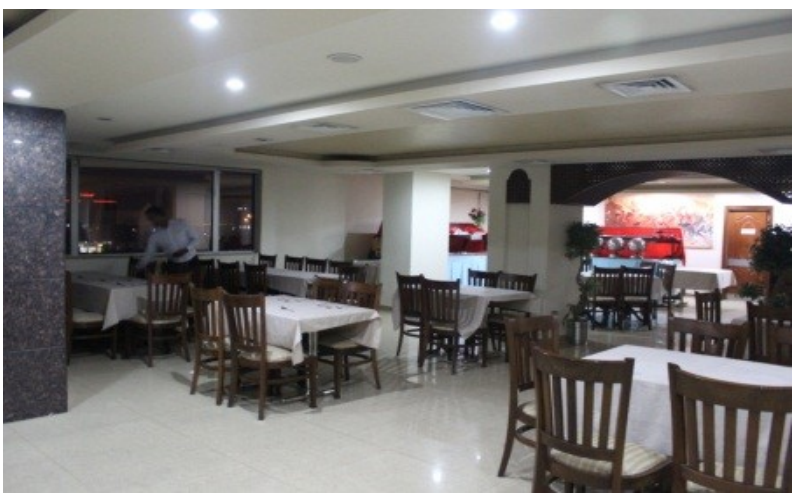

Figure 5. Restaurant 1 in White Light

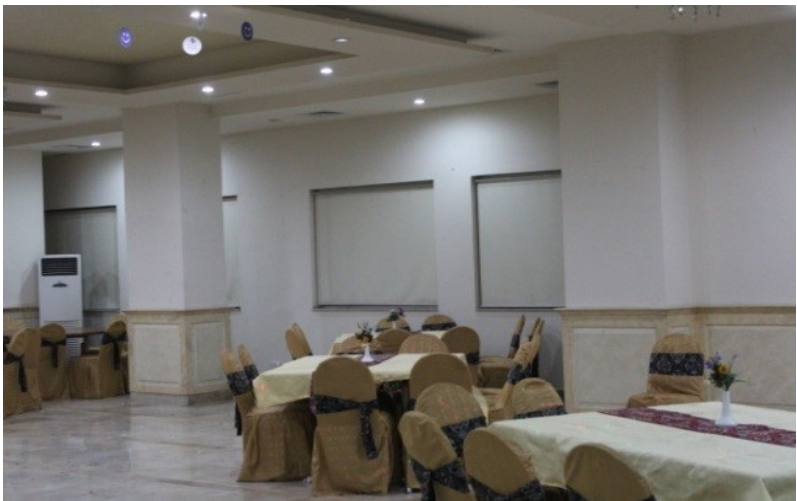

Figure 6. Restaurant 2 in White Lighting

Personally, administered closed ended questionnaires were given to assemble first hand data. The questionnaire was taken from Omar et al and Ayaz amendments were incorporated according to the study. Five-point Likert scales were chosen to measure constructs, customer gratification, col or, light, and temperature [5] [6]. Each feature included four items. Statistical Package for Social Sciences (SPSS) version 16 was used to carry out the Analysis with these three basic hypotheses 
1: Null hypothesis: There is no correlation between income and age of customers and dine in frequency

Alternative hypothesis/: There is significant correlation between income and age of customers and dine in frequency

2: Null hypothesis: There is no association between demographic characteristics (gender/income) and customer's gratification

Alternative hypothesis: There is significant association between demographic characteristics (gender/income) and customer's gratification.

3: Null hypothesis: Cooling, Color and Lightning in restaurant have no significant impact on customer's gratification

Alternative hypothesis: Cooling, Color and Lightning in restaurant have significant impact on customer's gratification

\section{Data Analysis and Interpretations}

The data analysis is represented in tabular form, where the customer gratification was dependent variable and color, light and cooling were independent variables. Some of the abbreviations are assigned to the constructs in tables, given below:

Customer Gratification = CG, Ambient Color $=$ AC, Ambient Light $=$ AL, Ambient Cooling $=$ ACL

\subsection{Reliability and Validity Test}

The first step was to test the reliability and validity of the questionnaire, the value of Cronbach's alpha and the reliability coefficients were obtained as under:

Table 1. Test for Reliability of Questionnaire

\begin{tabular}{|c|c|c|}
\hline Constructs & $\begin{array}{c}\text { Cronbach's } \\
\text { coefficient }\end{array}$ & $\begin{array}{c}\text { Average Variance } \\
\text { Extracted }\end{array}$ \\
\hline C G & 0.757 & 0.853 \\
\hline Color & 0.823 & 0.845 \\
\hline Light & 0.780 & 0.723 \\
\hline Cooling & 0.746 & 0.771 \\
\hline
\end{tabular}

Table 1 indicates the value of Cronbach's alpha for each construct which is greater than 0.7 , so the questionnaire was found to be a reliable one.

Then validity of the questionnaire was tested. For construct validity the average variance extracted (AVE) from all constructs, exceeded the minimum criterion of 0.50 (table 1), formula was extracted from Hair et al [34].

Table 2 indicates the $\mathrm{R}$ value where (average variance extracted) AVE of gratification of customers and color were 0.812 and 0.845 respectively, which is evidently greater than the $\mathrm{R}^{2}$ value of these two constructs. Customer gratification and light has an AVE of 0.701 and 0.723 which is found to be greater than the R square. Customer gratification and cooling has an AVE of 0.649 and 0.771 which is clearly higher than the value of their combined $R$ square. Similarly, on pair wise comparisons, it can be easily seen that the AVE for the constructs is higher than the R square values of two constructs. This ensures that the questionnaire has discriminant validity.

Table 2. R square values of customer gratification, ambient color, light and cooling

\begin{tabular}{|c|c|c|c|c|}
\hline Variables & $\begin{array}{c}\text { Customer } \\
\text { Gratification }\end{array}$ & AC & AL & AC \\
\hline C G & 1 & & & \\
\hline A C & 0.812 & 1 & & \\
\hline A L & 0.701 & 0.449 & 1 & \\
\hline A CL & 0.649 & 0.456 & 0.278 & 1 \\
\hline
\end{tabular}

\section{Demographic Characteristics}

The sample of 354 customers had the following demographic characteristics

Table 3. Gender Distribution of the Respondents

\begin{tabular}{|c|c|c|}
\hline Gender & Frequency & Percentage (\%) \\
\hline Female & 167 & 47.2 \\
\hline Male & 187 & 52.8 \\
\hline Total & 354 & 100.0 \\
\hline
\end{tabular}

The table 3 is indicates that there were $47.2 \%$ males and $52.8 \%$ females in the sample, who participated as respondents.

Table 4. Income Distribution of the Respondents

\begin{tabular}{|c|c|c|}
\hline Income Level & Frequency & Percentage (\%) \\
\hline Low income & 20 & 5.6 \\
\hline Middle income & 203 & 57.3 \\
\hline High Income & 131 & 37.0 \\
\hline Total & 354 & 100.0 \\
\hline
\end{tabular}

'The Table 4 indicates that $57.3 \%$ of the respondents were belonging to the middle-income group while $37 \%$ belonged to higher income and only $5.6 \%$ were from lower income group.

Table 5. Age Distribution of the Respondents

\begin{tabular}{|c|c|c|}
\hline Age Level & Frequency & Percentage (\%) \\
\hline $15-25$ & 75 & 21.2 \\
\hline $25-35$ & 101 & 28.5 \\
\hline $35-45$ & 65 & 18.4 \\
\hline $45-55$ & 61 & 17.2 \\
\hline above 55 & 52 & 14.7 \\
\hline Total & 354 & 100.0 \\
\hline
\end{tabular}

The Table 5 indicates the age distribution of the 
respondents. It can be seen that about $85 \%$ of the respondents were less than 55 years of age.

Correlations between dine in frequency, age and income are calculated to find out the relationship between them

Table 6. Correlations between Dine in Frequency, Age and Income

\begin{tabular}{|c|c|c|c|c|}
\hline & & Age & Income & $\begin{array}{c}\text { Dine in } \\
\text { Frequency }\end{array}$ \\
\hline \multirow{3}{*}{ Age } & $\begin{array}{c}\text { Pearson } \\
\text { Correlation }\end{array}$ & 1 & -.007 & .087 \\
\hline & Sig. (2-tailed) & & .890 & .102 \\
\hline & $\mathrm{N}$ & 354 & 354 & 354 \\
\hline \multirow{3}{*}{ Income } & $\begin{array}{c}\text { Pearson } \\
\text { Correlation }\end{array}$ & -.007 & 1 & $.540^{* *}$ \\
\hline & Sig. (2-tailed) & .890 & & .000 \\
\hline & $\mathrm{N}$ & 354 & 354 & 354 \\
\hline \multirow{3}{*}{$\begin{array}{l}\text { Dine in } \\
\text { Frequency }\end{array}$} & $\begin{array}{c}\text { Pearson } \\
\text { Correlation } \\
\end{array}$ & .087 & $.540^{* *}$ & 1 \\
\hline & Sig. (2-tailed) & .102 & .000 & \\
\hline & $\mathrm{N}$ & 354 & 354 & 354 \\
\hline
\end{tabular}

The Table 6 indicates the value correlation coefficient between age and dine in frequency is 0.087 which is insignificant, concluding that there is no significant correlation between age and dine in frequency while the correlation between income and dine in frequency is 0.54 which is highly significant ( $p$ value $=0.00$ ) and positive concluding as the income increases, the dine in frequency also increases.

\section{Test of Association}

Chi Square Test of Association is used to test the association between the demographic factors and customers gratification.

\subsection{Gender and Customers Satisfaction}

$\mathrm{H}_{04}$ : There is no association between gender and customer's satisfaction

$\mathrm{H}_{4}$ There is association between gender and customer's satisfaction.

Table 7. Gender * satisfaction Cross Tabulation

\begin{tabular}{|c|c|c|c|}
\hline & Not Satisfied & Satisfied & Total \\
\hline Female & 36 & 131 & 167 \\
\hline Male & 47 & 140 & 187 \\
\hline Total & 83 & 271 & 354 \\
\hline
\end{tabular}

The table 7 indicates the cross tabulation of gender and satisfaction. It can be seen that most respondents are satisfied and responses are homogeneously distributed between the two gender groups.

The table 8 is indicating the value of chi square $=0.629$ which is statistically insignificant $(\mathrm{p}=0.428>0.05)$ which indicates that customer's satisfaction is not associated with the gender.
So the null hypothesis is accepted.

Table 8. Chi-Square Test

\begin{tabular}{|c|c|c|c|c|c|}
\hline & Value & $\mathrm{df}$ & $\begin{array}{c}\text { Asymptotic } \\
\text { Sig. } \\
\text { (2-sided) }\end{array}$ & $\begin{array}{c}\text { Exact } \\
\text { Sig. } \\
\text { (2-sided) }\end{array}$ & $\begin{array}{c}\text { Exact } \\
\text { Sig. } \\
\text { (1-sided) }\end{array}$ \\
\hline $\begin{array}{c}\text { Pearson } \\
\text { Chi-Square }\end{array}$ & $.629 \mathrm{a}$ & 1 & .428 & & \\
\hline $\begin{array}{c}\text { Continuity } \\
\text { Correction } \\
\text { b }\end{array}$ & .445 & 1 & .505 & & \\
\hline \\
$\begin{array}{l}\text { a. } 0 \text { cells }(0.0 \%) \text { have expected count less than 5. The minimum } \\
\text { expected count is 39.16. }\end{array}$
\end{tabular}

\subsection{Income and Customers Satisfaction}

Null Hypothesis: There is no association between income and customer's satisfaction

Alternative Hypothesis: There is association between income and customer's satisfaction.

Table 9. Income*satisfaction Cross Tabulation

\begin{tabular}{|c|c|c|c|}
\hline & Not Satisfied & Satisfied & Total \\
\hline Low income & 5 & 15 & 20 \\
\hline Middle income & 51 & 152 & 203 \\
\hline high Income & 27 & 104 & 131 \\
\hline Total & 83 & 271 & 354 \\
\hline
\end{tabular}

The Table 9 indicates the cross tabulation of income and satisfaction. It can be seen that most respondents are satisfied and responses are distributed between the three income groups.

Table 10. Chi-Square Test

\begin{tabular}{|c|c|c|c|}
\hline & Value & df & $\begin{array}{c}\text { Asymptotic Sig. } \\
\text { (2-sided) }\end{array}$ \\
\hline $\begin{array}{c}\text { Pearson } \\
\text { Chi-Square }\end{array}$ & $.932 \mathrm{a}$ & 2 & .628 \\
\hline Likelihood Ratio b & .944 & 2 & .624 \\
\hline $\begin{array}{l}\text { a. } 1 \text { cells (16.7\%) have expected count less than 5. The minimum } \\
\text { expected count is 4.69. }\end{array}$
\end{tabular}

The Table 10 indicates the value of chi square $=0.932$ which is statistically insignificant $(p=0.628>0.05)$ which indicates that customer's satisfaction is not associated with their income.

\subsection{Binary Logistic Regression Model to analyze the Impact of Cooling, Lightning and Color Ambience on Customer's Gratification as a Mode to Increase Revenue}

The study targets at analyzing effect of cooling lights and color ambience on the customers' satisfaction as a mode to increase revenue.

The model has three predictors color light and cooling ambience and one binary dependent variable $\mathrm{Y}=$ $\mathrm{CG}=$ Gratification/satisfaction where

$\mathrm{Y}=0$ for unsatisfied customer

$\mathrm{Y}=1$ for satisfied customers 
We denote $\mathrm{p}=\mathrm{P}(\mathrm{Y}=1)$ and assume a linear relationship between predictors and the log odds of the event $y=1$ (satisfaction), then the model can be written as

$$
l=\log _{10} \frac{p}{1-p}=\beta_{0}+\beta_{1} A C+\beta_{2} A L+\beta_{3} A C L
$$

Where $\mathrm{AC}=$ Color,

$\mathrm{AL}=$ Light

ACL $=$ Cooling

$\beta_{0}=$ Constant

$\beta_{1}, \beta_{2}$ and $\beta_{3}$ are the coefficients of $\mathrm{C}, \mathrm{L}$ and $\mathrm{CL}$ respectively.

The odds can be obtained by exponentiation of the log-Odds

$$
\frac{p}{1-p}=10^{\beta_{0}+\beta_{1} C+\beta_{2} L+\beta_{3} C L}
$$

The data were analyzed using SPSS and the following results are obtained

Table 11. Omnibus Tests of Model Coefficients

\begin{tabular}{|c|c|c|c|c|}
\hline & & Chi-square & Df & Sig. \\
\hline Step 1 & Step & 83.244 & 3 & .000 \\
\hline & Block & 83.244 & 3 & .000 \\
\hline & Model & 83.244 & 3 & .000 \\
\hline
\end{tabular}

The table 11 indicates that the logit model is significant as $\mathrm{p}$ values are 0.00 which is less than the pre-assumed alpha 0.05 .

\begin{tabular}{|c|c|c|c|}
\hline Step & $\begin{array}{c}-2 \text { Log } \\
\text { likelihood }\end{array}$ & $\begin{array}{c}\text { Cox \& Snell R } \\
\text { Square }\end{array}$ & $\begin{array}{c}\text { Nagelkerke R } \\
\text { Square }\end{array}$ \\
\hline 1 & $302.342^{\mathrm{a}}$ & .210 & .316 \\
\hline
\end{tabular}

Table 12. Model Summary

The Table 12 indicates the summary of the model with Cox and Snell value or $\mathrm{R}$ square $=.210$ which is showing the model prediction also the Nagelkerke R square value of 0.316 which is also good for logit models.

The Table 13 indicates the results of the testing of the coefficients of the logistic regression model, it can be seen that all the three coefficients if cooling lightning and color are statistically significant. The constant is also found to be significant thus all the predictors have significant impact on the customer's gratification

The logit model is given as

$$
l=\log _{10} \frac{p}{1-p}=-2.847+0.396 C+.194 L+.153 C L
$$

Table 13. Variables in the Equation

\begin{tabular}{|c|c|c|c|c|c|c|c|}
\hline & Value & B & S.E. & Wald & Df & Sig. & Exp(B) \\
\hline Step 1a & Color & .369 & .062 & 35.032 & 1 & .000 & 1.447 \\
\hline & Light & .194 & .086 & 5.070 & 1 & .024 & 1.214 \\
\hline & Cooling & .153 & .074 & 4.217 & 1 & .040 & .858 \\
\hline & Constant & -2.847 & .555 & 26.274 & 1 & .000 & .058 \\
\hline
\end{tabular}




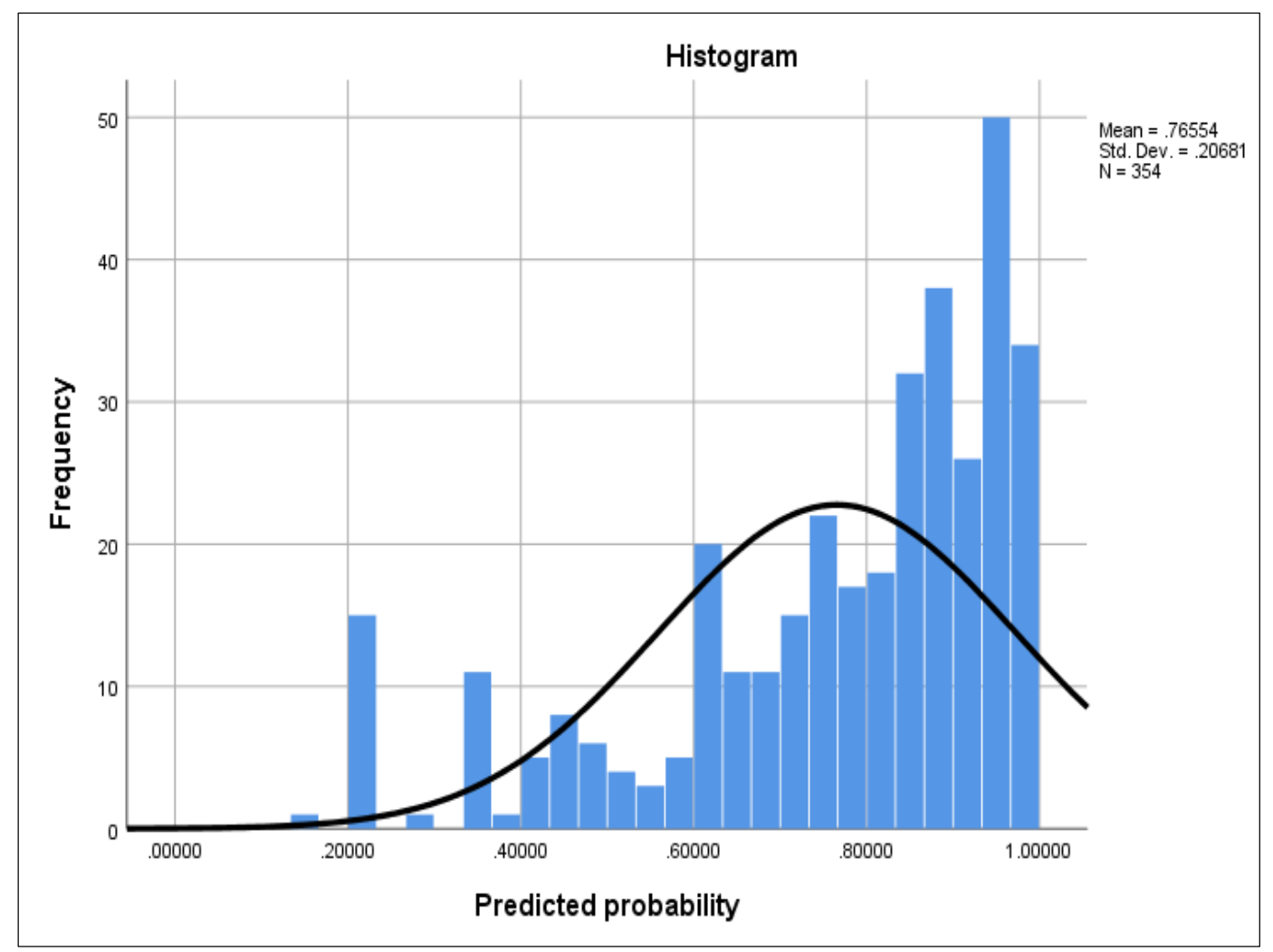

Figure 1. Histogram predicted probabilities of customer satisfaction using the binary logistic model

\subsection{Histogram of Predicted Probabilities}

The histogram in Figure 1 shows the predicted probabilities of customer satisfaction using the binary logistic model for the sample of 354 observations is given below. The mean of the predicted probabilities is 0.7854 showing that the chances of customers gratification as predicted by the model are greater than 0.5 .

\section{Inferences and Analysis}

The impact of cooling, lighting and color ambience on the customers gratification has been studied by applying a binary logistic model which is found to be significant and also the model parameters are significant showing that the three features have significant impact on customers gratification. Also, we have found the correlation between age and dine in frequency and income and dine in frequency. The correlation coefficient between the income and dine in frequency was highly significant and positive showing that dine in frequency increases with the increase in income. Association between customer's satisfaction and age and association between customer's satisfaction and gender was found to be statistically insignificant. It can be concluded that if the color, cooling and light ambience is improved, which will result in increase in customer's satisfaction and can also help in generating increased revenues.

\section{Discussion and Conclusions}

The research reveals around the customer gratification and ambience conditions in restaurant industry. Overall, three ambient features color, light and cooling were considered which showed a positive relationship with customer gratification. The causal research design was adapted to find out the cause and effect relationship of customer gratification and ambience [35]. The restaurants of Shalimar Tower hotel were selected who had altered their ambience with food quality or service. The simple random sampling technique was used of a sample size of 354. Personally, administered closed ended questionnaires were given to assemble primary data. Five-point Likert scales were chosen to measure constructs, customer gratification, color, light, and temperature. Each feature included of four items. Regression analysis was applied on Statistical Package for Social Sciences (SPSS) Version 16. The coefficient of determination (R2) was applied to access the variability of customer gratification on the level of ambience features. The colors can also impact on customers' mood and emotions in a restaurant setting because of the strong perception by humans to value colors [23][24]. The customer gratification and ambient color are most linked to consumers' understanding that the human can perceive from the surroundings.

These results indicated that the administration at Shalimar restaurants should notice the application of colors in their place because customers give value to color. Light 
is considered as most impacting element on human as one can only see food properly in light. The light is also considered as most significant encompassing variable as it permits the customers' capacity to see the food in its most ideal manner. Along these lines, the executives ought to guarantee that when structuring the eatery light, each table ought to have its very own climate regarding the light as this prompt client satisfaction.

The three hypotheses were formulated to test the results so it was found there is significant correlation between income and age of customers and dine in frequency and there is significant association between demographic characteristics (gender/income) and customer's gratification along that Cooling, Color and Lightning in restaurant have significant impact on customer's gratification. Results showed that there is a positive relationship between customer gratification and light. Ayaz [6], Farooq and Ahmed [7], Farooq et al [8] Flynn et. Al [32] and [33] also concluded the similar results which supported the study that ambient light also positively impacts on customers' feelings, behavior and gratification. These results suggest that Shalimar restaurants must stress more on light levels in the interiors. The opportunity to modify the temperature in the restaurants for customers raises its value. The study also showed that there is a positive connection between room cooling and client delight. This is in accordance with other researchers' discoveries, Motoki, et al, Sharifi and Huang et al inferred that surrounding cooling decidedly influences client delight [25][26][34]. Generally, it is considered that the taste of food is the main factor to attract customers in the restaurant business but the ambience is also having strong influence on customer gratification [19][20]. Nonetheless, this exploration finding infers that restaurant supervisors can depend on surrounding conditions additionally as a reason for client gratification [21][22]. This examination approved that if interior ambience is improved it can also upgrade customer gratification in the restaurant experience. The results of binary regression were also significant and positive showing that improvement in color, lightning and cooling improves the overall customer's gratification which eventually leads to the increase in revenue of restaurants [6][7][8].

In accordance with the above outcomes, it is recommended that restaurants ought to connect more into exercises, for example, upgrading or altering the light so as to light up the space more. In addition, the analyst suggests that the outlet ought to have appropriate color choice as this urges client to participate in drive purchasing. The temperature should be balanced to arrive at the ideal level through cooling.

\section{REFERENCES}

[1] D. Chiguvi, Impact of Ambience Conditions on Customer
Satisfaction in the Restaurant Industry; Case Study of Debonairs Pizza Outlets in Botswana. International Journal of Science and Research, 6(2), 1825-1833, 2017.

[2] W. Kasapila, Young adult's satisfaction regarding dining experience in casual dining restaurant in Hatfield, Pretoria, 2006.

[3] M. J. Bitner, Servicescapes: The impact of physical surroundings on customers and employees. Journal of Marketing; Volume 56(2):57-71, 1992.

[4] V. A. Zeithaml, and M.J. Bitner, Services marketing: Integrating customer focus across the firm, (3rd Ed.). Boston, New York: Mcgraw-Hill, 2003.

[5] M. S. Omar, H. F. Ariffin, R. Ahmed, The Relationship between Restaurant Ambience and Customers' Satisfaction in Shah Alam Arabic Restaurants, Selangor. International Journal of Administration and Governance. 1 (4) Special, 1-8. ISSN 2077-4486, 2015.

[6] S. Ayaz, Comparison of Two Aesthetical Lighting Plans in Moderate Upscale Restaurants on Patron Turnover Rate (PTOR). Sci. Int. (Lahore), 27 (4), 3575-3578,2015 ISSN 1013-531,2015.

[7] S. Farooq, A. Ahmed. Designed Lighting Plan and its Impacts on Patron Turnover Rate in the Restaurants. Sci.Int.(Lahore), 28 (6), 203-206, 2016.

[8] S. Farooq, M. Khan, A. Ahmed Employees Comfort Level in Existing Lighting at Arfa Software Technology Park (ASTP): A Case Study. Sci.Int.(Lahore), 31 (5), 785-788, 2019.

[9] R. L. Oliver, Satisfaction: A behavioral perspective on the consumer, The McGraw-Hill Companies Inc., New York, 1997.

[10] Y. Jordaan, M. Prinsloo, Grasping service markets, 2001.

[11] J. Kivela, R. Inbakaran, J. Reece. Consumer research in the restaurant environment, $\mathrm{P}$ a r t 1: A conceptual model of dining satisfaction and return patronage, International Journal of Contemporary Hospitality Management; Volume 11(5):205-222., 1999.

[12] T. Y. Choi, R. Chu. Determinants of hotel guests satisfaction and repeat patronage in the Hong Kong Hotel industry; International Journal of Hospitality Management; Volume 3(20): 234-244, 2001.

[13] C. Park, Efficient or Enjoyable. Consumer value of eating out and fast food restaurant consumption in Korea; International Journal of Hospitality Management; Volume 1(23), 2004.

[14] S. Khan, S. M. Hussain, F. Yaqoob. Determinants of customer satisfaction in fast food industry; International Journal of Management and Strategy; Vol. 3(4): 78-88, 2012.

[15] R. T. Rust, A. J. Zohoric, Customer satisfaction, customer retention and market share, Journal of Retailing, 1993.

[16] A. M. Fiore, X. Yah, E. Yoh. Effects of a product display and environmental fragrancing on approach responses and pleasurable experiences: Psychology and Marketing; Volume 17(1): 27-54, 1999.

[17] S. A. Syed, C. Conway. Customer satisfaction in the 
restaurant industry: An exam of the transaction specific model. Journal of Services Marketing; UNLV Gaming Research and Review Journal, 7(1):21-31, 2006.

[18] K. Ryu, S. Jang, The effect of environmental perceptions on behavioral intentions through emotions: The case of upscale restaurants. Journal of Hospitality of Tourism Research, Volume (56) :72.79, 2007.

[19] R. J. Varey. Internal marketing: a review and some interdisciplinary research challenges. International Journal of Service Industry Management, 1995..

[20] H. Lim. Understanding American customer perceptions on Japanese food and services in the U.S. Unpublished master's thesis, University of Nevada, Las Vegas, 2010.

[21] R. Gifford. Light, decor, arousal, comfort and communication: Journal of Environmental Psychology; Vol. 8(3), 1988

[22] J. Baker, L. L. Berry, A. Parasuraman, The marketing impact of branch facility design; Journal of Retail Banking; Volume 10(2):33-42, 1988.

[23] D. L. Kurtz, K. E. Clow. Services marketing. Wiley, 1998.

[24] N. Stroebele, J. De Castro. Effect of ambience on food intake and food choice. Nutrition, 20(9), 821-838, 2004.

[25] K. Motoki, T. Saito, R. Nouchi, R. Kawashima, M. Sugiura, Light colors and comfortable warmth: Cross modal correspondences between thermal sensations and color lightness influence consumer behavior, Food Quality and Preference, 72, 45-55. 2019.

[26] S. Sharifi. When more pain is better: Role of need for uniqueness on service evaluations of observable service recovery, International Journal of Hospitality Management, 2019.
[27] A. E. Ciani. A study of how lighting can affect a guest's dining experience. Lowa State University, Graduate Thesis and Dissertation. Digital Repository@ LAwa State University. Retrieved May 30th 2014 from lib.dr.iastate.edu/cgi/viewcontent.cgi?article=2435\&context =etd

[28] A. Yuksel, F. Yusel, Measurement of tourist satisfaction with restaurant services: A segment based approach. Journal of Vacation Marketing, 9(1): 52-68, 2002.

[29] G. R. Steffy. Architectural Lighting Design (3rd Ed.). New York, NY: J. Wiley and Sons, 2008.

[30] J. E. Flynn. A study of subjective responses to low energy and nonuniform lighting systems. Lighting Design and Application, 7 (2), pp. 6-15, 1977.

[31] J. E. Flynn, G. J. Subisak. A procedure for qualitative study of light level variations and system performance. Journal of IES, 8(1), 28-35, 1978.

[32] J. E. Flynn, C. Hendrick, T. Spencer, O. Martyniuk. A guide to methodology procedures for measuring subjective impressions in lighting. Journal of Illuminating Engineering Society (8), 95-110, 1979.

[33] S. Farooq, F. Zubair, M. Arif Kamal. Assessment of Lighting Design of Restaurants with Reference to its Aesthetics and Function, Civil Engineering and Architecture, Horizon Research Publishing, USA, 8(4), 714-720, 2020.

[34] X. Huang, M. Zhang, M. K. Hui, S. R. Wyer. Warmth and conformity: The effects of ambient temperature on product preferences and financial decisions. Journal of Consumer Psychology https://doi.org/10.1016/j.jcps.2013.09.009, 2013.

[35] J. F. Hair, R. E. Anderson, R. L. Zatham, W. C. Black. Multivariate data analysis (5th ed.). UK: Prentice Hall International, 1998 